\title{
Coleoptera (Insecta) as forest fragmentation indicators in the Rio Negro sub-region of the Pantanal, Mato Grosso do Sul, Brazil
}

\author{
Favero, S. *, Souza, HA. and Oliveira, AKM. \\ Programa de Pós-graduação em Meio Ambiente e Desenvolvimento Regional, \\ Universidade Anhanguera - Uniderp, Rua Ceará, 333, Bairro Miguel Couto, \\ CP 2153,CEP 79003-010 Campo Grande, MS, Brazil \\ *e-mail: silvio.favero@pq.cnpq.br \\ Received October 14, 2010 - Accepted December 13, 2010 - Distributed April 30, 2011
}

\begin{abstract}
The purpose of this study was to evaluate the integrity of two forest fragments in Rio Negro Pantanal sub-region, using coleopterans as environmental indicators. The study was carried out at Santa Emilia Farm in the Rio Negro sub-

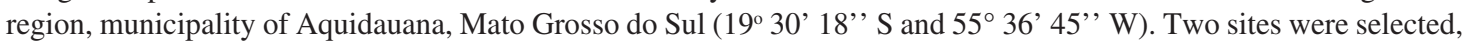
locally denominated as "cordilheiras" (narrow and elongated strands of elevated soil), one with low degree of anthropic disturbance (CL) and the other, currently undergoing restoration process (TD). The sampling sites were determined using a GPS device. Ten pit-fall traps containing water and detergent were used for the specimens sampling, which were screened and identified. Abundance, richness, diversity and similarity were determined. Abundance was higher for CL $(\mathrm{n}=277)$ than for TD $(\mathrm{n}=251)$. The same was observed for the diversity indices, $\mathrm{CL}$ showed $\mathrm{H}^{\prime}=2.83$ bit.individual $^{-1}$ and $\mathrm{TD}=2.48$ bit.individual $^{-1}$, confirming the interferences made for abundance. Specimens of ten families were captured in CL area and seven families in TD area, indicating higher richness in CL, when compared to TD. The linear correlation coefficient $(\mathrm{p}>0.05$ ) indicates that both areas are significantly different, showing similarity value of $66.7 \%$. The data show that the structure and disturbance degree in the environment integrity influence the composition of beetles fauna, causing the increase of abundance, richness and diversity in anthropogenic environments undergoing the early stage of regeneration.
\end{abstract}

Keywords: biodiversity, flood plain, insects, coleopterans.

\section{Coleoptera (Insecta) como indicadores de fragmentação florestal na sub-região do Pantanal do Negro, Mato Grosso do Sul, Brasil}

\begin{abstract}
Resumo
Este trabalho avalia a integridade de dois fragmentos de floresta da sub-região do Rio Negro do Pantanal, utilizando coleópteros como indicadores. O estudo foi conduzido na Fazenda Santa Emília, na sub-região do Rio Negro, município

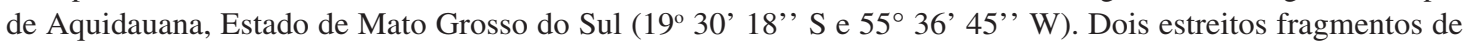
floresta (localmente conhecida com cordilheira), situados em terrenos um pouco mais elevados, um com baixo grau de perturbação antrópica (CL) e o outro em processo de restauração (TD). Os sítios de amostragem foram marcados com GPS. Dez armadilhas de queda contendo água e detergente foram utilizadas. Abundância, riqueza de espécie, diversidade e similaridade foram determinadas. Abundância foi maior para CL ( $n=277)$ do que para TD $(n=251)$. A mesma tendência foi observada para índices de diversidade, CL com 2,83 e TD com 2,48. Indivíduos de dez famílias foram capturados na área CL e de sete famílias na área TD, indicando mais alta riqueza em CL. O coeficiente de correlação linear $(\mathrm{p}>0,05)$ indica que ambas as áreas são significantemente diferentes, com valor de similaridade de $66,7 \%$. Os dados mostram que o grau de perturbação e estrutura da integridade ambiental influencia a composição da fauna de besouros, causando o aumento em abundância, riqueza e diversidade nos dois fragmentos estudados.
\end{abstract}

Palavras-chave: biodiversidade, planície de inundação, insetos, coleópteros. 


\section{Introduction}

A forest fragment can be defined as "any area of continuous natural vegetation, interrupted by anthropic barriers (roads, agricultural crops, etc.), or natural ones (lakes, other vegetation types, etc), capable of significantly reducing the flow of animals, pollen, and/or seeds" (Tabanez et al., 1997). The structure and dynamic of forest fragments vary depending on several factors, mainly the history of disturbance, the area's shape, the type of neighbouring environments and the isolation degree and, depending on these characteristics, can be self-sustaining or not (Tabanez et al., 1997).

Struminski and Lorenzotto (2003) emphasises the obvious importance of knowledge about fragmentation nowadays, because in many landscapes vast numbers of species are restricted to fragments. In the State of Mato Grosso do Sul, there is a typical ecosystem, popularly known as "Pantanal", with landscapes formed by complex of natural environments or habitats that comprise a set of natural forest fragments interspersed among ponds ("baías"), drainage channels ("vazantes" and "corixos") and rivers, forming a landscape mosaic.

In this region there are different vegetation physiognomies such as areas with riparian and gallery forests, savannas (forested, wooded and open grassland sub-types) which have several regional denominations such as "capões", "cordilheiras", "cambarazais", "paratudais", among others. Normally, these phytophysiognomies are not extensive, being interspersed with other landscape types. The gradient of forested, wooded, shrub and grassland formations is determined by topography, edaphic factors and mainly seasonal conditions like the dry and wet periods, because annual flooding, when more than $50 \%$ of the region is covered by water, contributes significantly to the formation of these environments (Magalhães, 1992).

The understanding of the biological dynamics of these habitats contributes to the comprehension of the Pantanal biome as a whole, allowing a diagnosis of the behaviour of certain species in existing forest fragments. One of the more accessible groups to this type of study, already used as environmental quality indicators, is that of entomofauna (Freitas et al., 2003).

Alho (2003) describes indicators as signs or evidences that enable researchers to verify the amplitude of variations which the observed phenomenon is suffering, due to specific processes or interventions. Therefore, various types of indicators can be established: context indicators - when is desired to monitor events or situations related to a wide region; process indicators - when what becomes important is the observation of the actions sequence or behaviour interactions, in a time scale; impact indicators - when the purpose is to check the effects pertinent to general goals, such as the number of species in an area designated for monitoring.

The use of indicator species to assess and monitor biological processes in the ecosystems dates from the early twentieth century. Later this concept was largely developed for the utilisation in pollution control in rivers and lakes. It is based on the use of species present in the community and subjected to some kind of evolutionary impact, in the past, or anthropogenic impact in the present (Correia, 2002).

Due to its biological importance, entomofauna is normally used as an evaluation parameter of fragmented areas. This group is one of the most important, because they comprise about $59 \%$ of all existing animals $(759,000$ species formally described), however they have been rarely used as "flagship species" in the conservation of natural areas. Although birds and mammals are most appreciated by conservationists in general, the usefulness of insects as environmental indicators is unquestionable. Some groups, among which butterflies, beetles and ants, are especially useful in environmental monitoring since they are easily sampled and identified, found all year round, and show fast response to environmental changes. Therefore, they can provide more information than vertebrates in general, due to their great usefulness in characterising small fragmented areas or with a long history of anthropogenic influence habitats, where many of the most sensitive and large vertebrates have already been eliminated by the reduction in living and hunting areas (Freitas et al., 2003).

Insect diversity influences ecosystem dynamics through numerous mechanisms such as litter decomposition, pollination, growth suppression of plants or serving as prey to carnivores. According to their role in ecosystem dynamics, these invertebrates are classified in three categories: explorers, acting as herbivores, parasitoids or predators; suppliers, serving as hosts to parasitoids or preys to predators; and facilitators, acting as pollinators, pathogen vectors or phoresy (Thomazini and Thomazini, 2000).

Regarding the choice of key insect groups for studies in fragmented forest systems, the most important ones are those capable of inducing physical changes in their environment and regulate the availability of resources to other species, such as pollinators, seed predators, parasitoids and decomposers (Didham et al., 1996).

Among these groups, the beetles of the family Scarabaeidae (Coleoptera) are used as indicators in studies on diversity of insects or arthropods and considered essential in studies on forest fragmentation, since much of the food (feces and carcasses) of this group is produced by organisms strongly affected by this process, such as birds, primates and other large mammals (Lovejoy et al., 1986). Furthermore, they are important in soil nutrients recycling, in the control of parasites of some vertebrates and in seed dispersal (Klein, 1989). The utilization of these beetles as indicators in biodiversity survey programmes has also been suggested, owing to the great morphological, taxonomic, ecological and behavioural variability, sensitivity to environmental changes and abundance (Thomazini and Thomazini, 2000).

Accordingly, this study aims to evaluate the integrity of forest fragments in the Rio Negro Pantanal sub-region, using Coleoptera species as environmental indicators. 


\section{Material and Methods}

The study was conducted at Santa Emilia Farm (Rio Negro Pantanal's sub-region), municipality of Aquidauana, Mato Grosso do Sul, 270 km from Campo Grande, where the Instituto de Pesquisa do Pantanal - IPPAN, of Universidade para o Desenvolvimento do Estado e da Região do Pantanal - UNIDERP, is situated. In this area there is a diversity of environmental conditions, with a large variety of vegetation types including riparian and gallery forests, which occupy large areas along the "Correntoso River", and the typical forests of "cordilheiras", narrow and elongated strands of elevated soil (1-2 m) above floodable grasslands. It has been suggested that they are ancient dunes covered by "cerradão" vegetation (forested savanna), presenting tall trees (12-16 m) and shorter ones (3-7 m) (Alho and Gonçalves, 2005).

The woody vegetation of this formation, with its sandy soil, has typical species, with emphasis on the occurrence of "Cambará" (Volchysia divergens, Pohl), "Tarumã" (Vitex cymosa Bertero), "Jatobá mirim” (Hymenaea sp. L.), "Ximbuva" (Enterolobium sp. Mart.), "Novateiro" (Triplaris americana L.), "Paratudo" (Tabebuia aurea (Manso)), "Manduvi" (Sterculia apetala (Jacq)), "Piuva" (Tabebuia sp. Gomes ex D.C.), "Gonçalo" (Astronium fraxinifolium Scott), "Embaúba" (Cecropia pachystachya Trec.), "Acuri" (Attalea phalerata Mart.), "Figueiras" (Ficus sp. L.), "Pequi" (Caryocar brasiliense L.), "Bocaiúva" (Acrocomia aculeata Jacq.), "Lixeira” (Curatella americana L.), "Cumbaru" (Dipteryx alata Vog.), "Maminha-de-porca" (Zanthoxylum rigidum Humb). In the shrub stratum, the presence of representatives of the families Rubiaceae and Myrtacea was registered, among others (Pott and Pott, 2003). In the vicinity of the "cordilheira", natural grasslands are encountered constituted by "capim barba-develho" (Pterocaulon virgatum D.C.) and "capim navalha" (Scleria melaleuca Rchb. ex Schltdl. \& Cham.), where scattered clumps of "Canjiqueiras" (Birsonima sp Rich ex Kunth.) are found.

For the field work execution and data sampling, two sites with low anthropogenic influence and 3,096.42 m apart from each other were previously established. In the past, selective extractions of wood were undertaken in these locations, but are currently undergoing advanced regeneration process.

The first site is located near the region locally known as "baía do cervo", which is bordered by a "cordilheira" that received the denomination "Cordilheira das Três Divisas" (TD), located at $19^{\circ} 30^{\prime} 23^{\prime}$ ' $\mathrm{S}$ and $55^{\circ} 35^{\prime} 32^{\prime}$ ' W.

The second site is located near the Santa Marta Farm boundary, in a "cordilheira" that received the denomination "Cordilheira do Lau" (CL), located at $19^{\circ} 29^{\prime \prime} 24$ "' S and $55^{\circ} 36$ ' $38^{\prime}$ ' $\mathrm{W}$.

The sampling effort was undertaken through the installation of 10 pit-fall traps, containing water and detergent, and the captured insects were collected at dawn (Almeida et al., 1998). Four sampling sessions were performed.
The sampled specimens were stored in glass bottles properly covered and containing ethylic alcohol (70\%), which were labelled (date, sampling place and time) and transported to the Entomology Lab of Anhanguera-Uniderp University for screening, taxonomic identification and, then, deposited in the scientific collection. Statistical treatment was performed to determine the abundance, richness (jackknife1), diversity (Shannon index, log 10), similarity (SØrensen) and evenness of the species occurring in the sampling sites (Krebs, 1989).

\section{Results and Discussion}

\subsection{Abundance and diversity}

In this study, 528 coleopterans distributed in 10 families were collected. The largest number of specimens (277) was captured in the area denominated "Cordilheira do Lau" (CL), and the lowest number in "Cordilheira das Três Divisas" (TD) (251) (Table 1).

Abundance was higher in CL, which demonstrates the advanced restoration degree of the vegetation compared to the TD area. The greater abundance in the CL area is due to the higher number of species of the family Scarabaeidae (13) collected during the four samplings and also to the significant occurrence of the species 5 of Scarabaeidae (134) in the first sampling in CL area (Table 1). These insects help in dispersal and burial of seeds, with potential long-term effects on forest maintenance or restoration (Lewinsohn et al., 2005). Similar results were obtained by Marinoni and Ganho (2003, 2006) and Ganho and Marinoni (2003) in anthropogenic areas of Araucaria in the state of Paraná.

These numbers may be associated with the greater diversity of feeding habits of the coleopterans and to the greater availability of floristic resources in regeneration areas. The elevated number of individuals of certain plant species leads to large production of fruits, that attract specific coleopterans and mammals that feed on them, leaving in place large amount of feces, which also attract other organisms. Hutcheson (1990) mentions that in more open habitats at the climax stage and dominated by shrubs, fewer individuals were captured comparing to restoration areas, in the same ecosystem type.

This feature can also be observed when comparing the diversity indices calculated for each studied area, CL showed $\mathrm{H}^{\prime}=2.83$ bit. individuals ${ }^{-1}$ and TD H'= 2.48 bit.indivíduo $^{-1}$, confirming the inferences made for abundance (Table 2).

\subsection{Family richness}

Ten families were found in the CL area and seven families in TD, consequently CL showed greater family richness (Tables 1 and 2).

Regarding the Brazilian coleopterofauna, Costa Lima (1952) listed 112 families, Costa et al. (1988) listed 109 families, and Costa (1999) 106 families. This variation is an outcome of constant revisions of the coleopterans classification. In the present work, the low family richness found is probably due to the sampling method, since the 
attractants, baits or lures were not used in the traps, which were randomly installed in the studied areas.

The greatest richness in CL can be explained by the highest productivity of this area, that displays regeneration degree with higher regrowth, flowering and leaves and fruits falling, that provide resources for phytophagous species, besides the presence of feces and carcasses resulting from

Table 1. Families of Coleoptera collected in two "cordilheiras" of Rio Negro Pantanal sub-region, Santa Emília Farm, Mato Grosso do Sul.

\begin{tabular}{|c|c|c|c|}
\hline Taxon & Morphotype & $\mathbf{T D}^{1}$ & $\mathrm{CL}^{1}$ \\
\hline Bruchidae & 1 & 0 & 1 \\
\hline \multirow[t]{8}{*}{ Carabidae } & 1 & 9 & 4 \\
\hline & 2 & 63 & 44 \\
\hline & 3 & 1 & 2 \\
\hline & 4 & 1 & 1 \\
\hline & 5 & 0 & 1 \\
\hline & 6 & 2 & 1 \\
\hline & 7 & 0 & 4 \\
\hline & 8 & 1 & 1 \\
\hline Cerambycidae & 1 & 0 & 1 \\
\hline \multirow[t]{4}{*}{ Chrysomelidae } & 1 & 3 & 3 \\
\hline & 2 & 2 & 2 \\
\hline & 3 & 1 & 1 \\
\hline & 4 & 0 & 1 \\
\hline \multirow[t]{3}{*}{ Curculionidae } & 1 & 18 & 11 \\
\hline & 2 & 9 & 3 \\
\hline & 3 & 1 & 0 \\
\hline Histeridae & 1 & 1 & 1 \\
\hline \multirow[t]{2}{*}{ Nitidulidae } & 1 & 0 & 2 \\
\hline & 2 & 1 & 3 \\
\hline Staphilinidae & 1 & 0 & 3 \\
\hline \multirow[t]{13}{*}{ Scarabaeidae } & 1 & 118 & 33 \\
\hline & 2 & 1 & 1 \\
\hline & 3 & 11 & 9 \\
\hline & 4 & 5 & 2 \\
\hline & 5 & 0 & 134 \\
\hline & 6 & 0 & 1 \\
\hline & 7 & 0 & 1 \\
\hline & 8 & 0 & 1 \\
\hline & 9 & 0 & 1 \\
\hline & 10 & 0 & 1 \\
\hline & 11 & 0 & 1 \\
\hline & 12 & 1 & 1 \\
\hline & 13 & 1 & 0 \\
\hline \multirow[t]{2}{*}{ Tenebrionidae } & 1 & 1 & 0 \\
\hline & 2 & 0 & 1 \\
\hline Total & $-\mathrm{X}-$ & 251 & 277 \\
\hline
\end{tabular}

1/TD = "Cordilheira das Três Divisas"; CL = "Cordilheira do Lau". the native mammalian fauna (feral pigs, capybaras, tapirs, primates) and birds. Agropastoral activity within and in the surrounding area also serves as a resource for necrophagus and coprophagus species, which feed on these ruminants feces as explained by Thomazini and Thomazini (2000). Therefore, it is possible to observe that the difference between the areas may be conditioned by the presence of rare individuals and not by the degree of preservation, as affirmed by Ganho and Marinoni (2003).

\subsection{Community structure}

\section{Similarity}

The structures of coleopteran communities in the TD and CL areas, based on the total values of species abundance, are not significantly similar (linear correlation coefficient $\mathrm{p}>0.05$ ) (Table 2).

Both sampling areas demonstrate independent community structure, showing $66.7 \%$ similarity, due to the approximate number of species richness in each area, associated to the proportionally low number of shared species (17 species of the 54 registered) (Table 1). Considering that the physiognomic characteristics of the areas are different, and considering their floristic diversity, the similarity value of coleopterans species between the areas is low. Marinoni and Ganho (2003, 2006); Ganho and Marinoni (2003) researched areas of Araucaria forest in the state of Paraná, and found greater similarity between the different studied areas, however the dominance of a single plant species, the araucaria, favours the similarity between insect species since the floristic richness is the same.

\section{Conclusions}

The abundance and diversity of insects in the "CL", an area undergoing more advanced stage of floristic restoration, are higher than the "TD", undergoing initial stage of restoration. The same pattern was verified for family richness, indicating higher values for the "CL" site compared to the "TD" site, in less advanced stage of restoration. There is

Table 2. Estimated and maximum richness, estimated and maximum diversity, evenness and similarity between the two "cordilheiras" in the Rio Negro Pantanal sub-region, Santa Emília Farm, Mato Grosso do Sul, 2005.

\begin{tabular}{lcc}
\hline \multirow{2}{*}{ Parameter } & \multicolumn{2}{c}{ Fragment } \\
\cline { 2 - 3 } & CL' & TD \\
\hline Abundance & 277 & 251 \\
Richness (Jackknife) & 33 & 21 \\
Maximum richness (Jackknife) & 49.5 & 21 \\
Diversity (Shannon) & 1.9628 & 1.7166 \\
Maximum diversity (Shannon) & 3.4965 & 3.0445 \\
Evenness & 0.5613 & 0.5638 \\
\hline Similarity & 0.667 & $\mathrm{r}=0.288 \mathrm{~ns}$ \\
\hline CL = "Cordilheira do Lau”; TD = “Cordilheira das Três \\
Divisas”; 1/ns = non significant (p > 0.05).
\end{tabular}

Divisas"; $1 / \mathrm{ns}=$ non significant $(\mathrm{p}>0.05)$. 
significant difference in the coleopterofauna composition between the areas, showing a low coefficient of similarity. Therefore, the structure and the disturbance degree of the environments integrity influence coleopterofauna composition, causing the increase of abundance, richness and diversity in anthropogenic environments and those undergoing advanced stage of restoration.

\section{References}

ALHO, CJR., 2003. Conservação da biodiversidade da Bacia do Alto Paraguai. Campo Grande: Editora Uniderp, 2003. 466 p.

ALHO, CJR. and GONÇALVES, HC., 2005. Biodiversidade do Pantanal: ecologia \& conservação. Campo Grande: Ed.Uniderp. $142 \mathrm{p}$.

ALMEIDA, LM., RIBEIRO-COSTA, CS. and MARINONI, L., 1998. Manual de coleta, conservação, montagem e identificação de insetos. Ribeirão Preto: Holos. 78 p.

CORREIA, MEF., 2002. Potencial de Utilização dos Atributos das Comunidades de Fauna de Solo e de Grupos Chave de Invertebrados como Bioindicadores do Manejo de Ecossistemas. Seropédica: Embrapa Agrobiologia. 23 p. Embrapa Agrobiologia, Documentos, no. 157.

COSTA, C., 1999. Coleoptera linnaeus, 1758. In: JOLY, CA. and BICUDO, C., Org. Biodiversidade do Estado de São Paulo. Síntese do conhecimento ao final do século XX. São Paulo: FAPESP. p. 115-122.

COSTA, C., VANIN, SA and CASARI-CHEN, SA., 1988. Larvas de Coleoptera do Brasil. São Paulo: Museu de Zoologia, Universidade de São Paulo. 282 p.

COSTA LIMA, AM., 1952. Coleópteros. In: Costa Lima, AM. Insetos do Brasil. Rio de Janeiro: Escola Nacional de Agronomia. vol. 7. 372 p.

DIDHAM, RK., GHAZOUL, J., STORK, NE. and DAVIS, AJ., 1996. Insects in fragmented forests: a functional approach. Tree, vol. 11 , no. 6 , p. 255-260.

FREITAS, AVL., FRANCINI, RB. and BROWN Jr., K., 2003. Insetos como indicadores ambientais. In CULLEN Jr., L., RUDRAN, R. and VALLADARES-PADUA, C. Métodos de estudos em biologia da conservação \& manejo da vida silvestre. Curitiba: Ed. da UFPR; Fundação O Boticário de Proteção à Natureza. p. 125-151.

GANHO, NG. and MARINONI, RC., 2003. Fauna da Coleoptera no Parque Estadual de Vila Velha, Ponta Grossa, Paraná, Brasil.
Abundância e Riqueza das famílias capturadas através de armadilhas malaise. Revista Brasileira de Zoologia, vol. 24, no. 4, p. 727-736.

HUTCHESON, J., 1990. Characterization of terrestrial insect communities using quantified, Malaise-trapped Coleoptera. Ecological Entomology, vol. 15, p. 143-151.

KLEIN, BC., 1989. Effects of forest fragmentation on dung and carrion beetle communities in Central Amazonia. Ecology, vol. 70, no. 6, p. 1715-1725.

KREBS, CJ., 1989. Ecological methodology. New York: Harper-Collins. 654 p.

LEWINSOHN, TM., FREITAS, AVL. and PRADO, PI., 2005. Conservação de invertebrados terrestres e seus habitats no Brasil. Megadiversidade, vol. 1, no. 1.

LOVEJOY, TE., BIRREGAARD JUNIOR, RO. and RYLANDS, AB., 1986. Edge and other effects of isolation on Amazon forest fragments. In SOULÈ, ME., ed. Conservation biology: the science of scarcity and diversity. Sunderland: Sinauer Associates. p. 257-285.

MAGALHÃES, NW., 1992. Conheça o Pantanal. São Paulo: Terragraph. p. 390.

MARINONI, RC. and GANHO, NG., 2003. Fauna da Coleoptera no Parque Estadual de Vila Velha, Ponta Grossa, Paraná, Brasil. Abundância e Riqueza das famílias capturadas através de armadilhas de solo. Revista Brasileira de Zoologia, vol. 24, no. 4, p. 727-744.

-, 2006. A diversidade diferencial beta de Coleoptera (Insecta) em uma paisagem antropizada do Bioma Araucária. Revista Brasileira de Entomologia, vol. 50, no. 1, p. 64-71. 2006.

POTT, A. and POTT, V., 2003. Espécies de fragmentos florestais em Mato Grosso do Sul. In COSTA, RB. Fragmentação florestal e alternativas de desenvolvimento rural na região Centro-Oeste. Campo Grande: UCDB. p. 26-52.

STRUMINSKI, E. and LORENZETTO, A., 2003. A fragmentação de ecossistemas na Área de Proteção Ambiental - APA do Rio Passaúna - Região Metropolitana de Curitiba - PR. Cadernos da Biodiversidade/Diretório de Biodiversidade e Áreas Protegidas, vol. 4 , no. 1.

TABANEZ, AJ., VIANA, VM. and DIAS, AS.,1997. Conseqüências da fragmentação e do efeito de borda sobre a estrutura, diversidade e sustentabilidade de um fragmento de floresta de planalto de Piracicaba, SP. Revista Brasileira de Biologia = Brazilian Journal of Biology. vol. 57, no. 1, p. 47-60.

THOMAZINI, MJ. and THOMAZINI, APBW., 2000. A fragmentação florestal e a diversidade de insetos nas florestas tropicais úmidas. Rio Branco: Embrapa Acre. 21 p. Documentos, no. 57. 